\title{
NATURAL REGENERATION STRATUM AS AN INDICATOR OF RESTORATION IN AREA OF ENVIRONMENTAL COMPENSATION FOR MINING LIMESTONE, MUNICIPALITY OF BARROSO, MG, BRAZIL ${ }^{1}$
}

\author{
Wanuza Helena Campos ${ }^{2 *}$ and Sebastião Venâncio Martins ${ }^{3}$
}

\footnotetext{
${ }^{1}$ Received on 11.09.2013 accepted for publication on 27.11.2015.

${ }^{2}$ Universidade Federal de Viçosa, Departamento de Engenharia Florestal, Programa de Pós-Graduação em Ciência Florestal, Viçosa, MG - Brasil. E-mail:<wanuzacampos@yahoo.com.br>.

${ }^{3}$ Universidade Federal de Viçosa, Centro de Ciências Agrárias, Departamento de Engenharia Florestal, Viçosa, MG - Brasil. E-mail:<venancio@ufv.br>.

${ }^{*}$ Corresponding author.
}

\begin{abstract}
This study was conducted in a forest under restoration process, which belongs to the company Holcim Brasil S/A, in the municipality of Barroso, state of Minas Gerais $\left(21^{\circ} 00^{\prime}\right.$ to $22^{\circ} 00^{\prime} \mathrm{S}$ and $43^{\circ} 00^{\prime}$ to $\left.44^{\circ} 00^{\prime} \mathrm{W}\right)$, where 40 plots $(2 \times 2 \mathrm{~m})$ were set, spaced at $10 \mathrm{~m}$, forming eight strata parallel to the watercourse present in the area. Floristic composition and natural regeneration stratum were characterized, and the formed strata allowed evaluating whether the riparian vegetation and watercourse influence on the local regeneration. It was found 162 individuals of 13 families, 18 genera and 22 species, and 10,125 individuals/ha were estimated. Successional classes from pioneer and early secondary and zoochory dispersion syndrome prevailed among species and individuals. The watercourse and riparian vegetation did not exercise significant influence $(\mathrm{p}>$ 0.05 ) on the number of species and regenerating individuals among the different strata of the forest. The diversity index of Shannon-Wiener $\left(\mathrm{H}^{\prime}\right)$ and equability of Pielou $\left(\mathrm{J}^{\prime}\right)$ were 2.691 and 0.870 , respectively. The species Psidium guajava and Myrtaceae families presented the highest VI (value of importance). Natural regeneration analysis showed the low floristic diversity in the area, suggesting that corrective management actions should be adopted.
\end{abstract}

Keywords: Ecological restoration; Forest restoration; Restoration indicators.

\section{ESTRATO DE REGENERAÇÃO NATURAL COMO INDICADOR DO PROCESSO DE RESTAURAÇÃO EM ÁREA DE COMPENSAÇÃO AMBIENTAL PELA MINERAÇÃO DE CALCÁRIO, MUNICÍPIO DE BARROSO, MG, BRASIL}

\begin{abstract}
RESUMO - Este estudo foi realizado em uma floresta em processo de restauração pertencente à empresa Holcim Brasil S/A, no Municipio de Barroso, Minas Gerais $\left(21^{\circ} 00^{\prime}\right.$ a $22^{\circ} 00^{\prime} S$ e $43^{\circ} 00^{\prime}$ a $\left.44^{\circ} 00^{\prime} \mathrm{W}\right)$, onde foram instaladas 40 parcelas de $2 \times 2 \mathrm{~m}$, espaçadas em $10 \mathrm{~m}$, formando 8 estratos paralelos ao curso d'água presente na área. Nestas parcelas caracterizou-se florística e estruturalmente o estrato de regeneração natural e os estratos formados permitiram avaliar se a mata ciliar e o curso d'água influenciam na regeneração do local. Foram observados 162 indivíduos, pertencentes a 13 famílias, 18 gêneros e 22 espécies, sendo estimados 10.125 individuos/ ha. As classes sucessionais das pioneiras e secundárias iniciais e a síndrome de dispersão zoocórica prevaleceram entre as espécies e indivíduos. O curso d'água e a mata ciliar não exerceram influência significativa $(p>0,05)$ sobre o número de espécies e indivíduos regenerantes entre os diferentes estratos da floresta. Oíndice de diversidade de Shannon-Wiener $\left(H^{\prime}\right)$ e a equabilidade de Pielou $\left(J^{\prime}\right)$ foram, respectivamente, 2,691 e 0,870. A espécie, Psidium guajava e a famílias Myrtaceae apresentaram os maiores VI (Valor de importância). A análise da regeneração natural evidenciou a baixa diversidade florística da área, sugerindo que sejam adotadas ações de manejo corretivo.
\end{abstract}

Palavras-chave: Restauração ecológica; Restauração florestal; Indicadores de restauração. 


\section{INTRODUCTION}

Despite the economic importance, limestone mining can promote considerable negative environmental impacts such as the suppression of native vegetation for the opening of new mining areas (MARTINS NETO; RAMALHO, 2010). Therefore, on the legal scope, there has been a particular concern about mining activities, as for example, the Law 11.428/2006, which provides the adoption of a compensatory measure that, includes forest restoration of an area equivalent to the mining project area.

Once the process of restoring these environments starts, it is necessary to evaluate and monitor them to check if the proposed goals were met. For this purpose, the evaluation markers and monitoring tools were used. Those are tools used to detect whether the process of succession needs or does not need intervention (MARTINS, 2009), and to conclude whether the environment has already a position for self-supporting, as well.

The regenerating stratum is young individuals or seedlings that inhabit the forest understory and allows the self-perpetuation of plant community over time (RODRIGUES et al., 2009). The evaluation of the natural regeneration under the canopy of areas at restoration process is an important tool for analyzing the evolution of restauration communities (MELO; DURIGAN, 2007) according to Marangon et al. (2008), regeneration results from the interaction of restoring natural processes of the ecosystem, being part of the development cycle and the forest setting up.

On the other hand, the identification of ecological barriers that prevent or hinder natural regeneration and decrease the self-perpetuation of the ecosystem is an essential factor for the adaptation of restoration methods and for the adoption of correction management techniques (ENGEL and PARROTA, 2003; RODRIGUES etal., 2011).

The objective of this study was to use natural regeneration stratum as an indicator of restoration process performed as environmental compensation for limestone mining in the municipality of Barroso, state of Minas Gerais, through the floristic and structural analysis.

\section{MATERIALAND METHODS}

\subsection{Study area}

The study was carried out in an area under seven years of restauration process, which belongs to the company Holcim Brasil S/A in the municipality of Barroso
(21Ú00' to 22Ú00'S and 43Ú00' to 44Ú00' W), state of Minas Gerais, in the middle region of Campos das Vertentes. The climate is classified as Cwb (Köppen), that is, mesothermal with well-defined seasons (OLIVEIRA-FILHO; MACHADO, 1993). The average annual temperature in the city is $18.8^{\circ} \mathrm{C}$ and average annual rainfall of $1300 \mathrm{~mm}$. The soils in the area are predominantly Yellow-Red Latosol and haplic cambisol (EMBRAPA, 2006). The altitude in the municipality ranges from $900 \mathrm{~m}$ to $1,200 \mathrm{~m}$. As for the vegetation, the occurrence of semi-deciduous forest, riparian forest and Cerrado-field (Brazilian savannah) stand out (MENINI NETO et al., 2004).

The place of study presents approximately 13 ha and its surroundings consist of pastures, mine dumps, a stream named "Córrego do Monjole " as well as areas of natural regeneration process, belonging to the company Holcim Brasil S/A. The vegetation in the study area results from a planting of native and exotic species (Table 1), spaced by 3 x $3 \mathrm{~m}$, totaling approximately 555 individuals and 30 species. The implementation was carried out in 2006 by the company Holcim Brasil $\mathrm{S} / \mathrm{A}$ as a compensatory measure for limestone mining carried out by the company. Before restoration, the site was dominated by Urochloa sp. pasture and some individual trees located on the banks of the watercourse.

\subsection{Characterization of natural regeneration}

At the study site, a 0.5 ha area was delimited, where 40 plots of $2 \times 2 \mathrm{~m}$, spaced at $10 \mathrm{~m}$ were enclosed for the evaluation of regenerating individuals. Therefore, eight strata were formed parallel to the watercourse, composed of five plots, where the stratum 1 was the closest and stratum 8 the most distant from the stream (Figure 1) in order to evaluate the interference of the watercourse as well as the riparian vegetation on the natural regeneration of forest under restoration.

All shrub-tree individuals with a height equal to or higher than $30 \mathrm{~cm}$ and $\mathrm{CBH}$ (circumference at breast height of 1.30) of less than $15.0 \mathrm{~cm}$, present in the plots were identified and had their respective diameter measured at the ground level and total height measured. The sampled species were further classified into successional categories: pioneers, early secondary, late secondary and unclassified (GANDOLFI et al., 1995; MARTINS; RODRIGUES, 2005) and, according to their seed dispersal syndromes: zoochory, anemochory and autochory (van der PIJL, 1982). 
Table 1 - List of species used in planting the forest under restoration process, company Holcim Brasil S/A, Barroso, MG. Table 1 - Relação das espécies utilizadas no plantio da floresta em processo de restauração, empresa Holcim Brasil S/ A, Barroso, $M G$.

\begin{tabular}{|c|c|c|}
\hline Species & Family & $\mathrm{N} / \mathrm{E}$ \\
\hline Albizia niopoides (Spruce ex Benth.) Burkart & Fabaceae & $\mathrm{N}$ \\
\hline Anadenanthera macrocarpa (Benth.) Brenan & Fabaceae & $\mathrm{N}$ \\
\hline Bauhinia variegata $\mathrm{L}$. & Fabaceae & $\mathrm{E}$ \\
\hline Bixa orellana L. & Bixaceae & $\mathrm{N}$ \\
\hline Caesalpinia peltophoroides Benth. & Fabaceae & $\mathrm{N}$ \\
\hline Cedrela fissilis Vell. & Meliaceae & $\mathrm{N}$ \\
\hline Ceiba speciosa (A. St.-Hil.) Ravenna & Malvaceae & $\mathrm{N}$ \\
\hline Croton floribundus Spreng. & Euphorbiaceae & $\mathrm{N}$ \\
\hline Croton urucurana Baill. & Euphorbiaceae & $\mathrm{N}$ \\
\hline Dalbergia nigra (Vell.) Allemão ex Benth. & Fabaceae & $\mathrm{N}$ \\
\hline Enterolobium contortisiliquum (Vell.) Morong. & Fabaceae & $\mathrm{N}$ \\
\hline Erythrina falcata Benth. & Fabaceae & $\mathrm{N}$ \\
\hline Guazuma ulmifolia Lam. & Malvaceae & $\mathrm{N}$ \\
\hline Handroanthus heptaphyllus (Vell.) Mattos & Bignoniaceae & $\mathrm{N}$ \\
\hline Handroanthus serratifolius (Vahl) S. O. Grose & Bignoniaceae & $\mathrm{N}$ \\
\hline Hymenaea courbaril L. & Fabaceae & $\mathrm{N}$ \\
\hline Inga vera Willd. & Fabaceae & $\mathrm{N}$ \\
\hline Jacaranda mimosifolia D. Don & Bignoniaceae & $\mathrm{E}$ \\
\hline Lafoensia pacari A. St. -Hil. & Lythraceae & $\mathrm{N}$ \\
\hline Lithraea molleoides Engl. & Anacardiaceae & $\mathrm{N}$ \\
\hline Luehea grandiflora Mart. & Malvaceae & $\mathrm{N}$ \\
\hline Morus nigra $\mathrm{L}$. & Moraceae & $\mathrm{E}$ \\
\hline Peltophorum dubium (Spreng.) Taub. & Fabaceae & $\mathrm{N}$ \\
\hline Psidium guajava $\mathrm{L}$. & Myrtaceae & $\mathrm{N}$ \\
\hline Samanaea inopinata (Harms) Ducke & Fabaceae & $\mathrm{N}$ \\
\hline Schinus molle L. & Anacardiaceae & $\mathrm{N}$ \\
\hline Schinus terebinthifolia Raddi & Anacardiaceae & $\mathrm{N}$ \\
\hline Schizolobium parahyba (Vell.) S. F. Blake & Fabaceae & $\mathrm{N}$ \\
\hline Trichilia catigua A. Juss. & Meliaceae & $\mathrm{N}$ \\
\hline
\end{tabular}

N: native; E: exotic.

By using Fitopac 2.1 software (SHEPHERD, 2010), the following parameters were calculated: density, frequency, dominance, importance value, described by Mueller-Dombois and Ellenberg (1974), the diversity index of Shannon-Wiener (H') (MAGURRAN, 1998) and equability (J') (PEILOU, 1975).

Sum and percentage of individuals and species were obtained in each successional category and dispersion syndrome. To verify the effect of distance of the watercourse and riparian vegetation on species richness and number of regenerating individuals, each stratum was considered a treatment and each plot, a replicate. The means calculated for the number of species and the number of individuals per stratum were compared using analysis of variance (ANOVA) using the F test. Later, the Tukey test was applied at a level of $5 \%$ of significance. Statistical analyzes were performed using STATISTICA 7.0 software (STATSOFT, 2004).

\section{RESULTS}

This study sampled 162 individuals of 13 families, 18 genera and 22 species (Table 2), where all species were native. An estimated density of 10,125 individuals/ ha was estimated. Out of the 30 species used in the planting, $24(80 \%)$ were not found in the stratum of natural regeneration, and only Lithrea molleoides, Schinus terebinthifolia, Croton urucurana, Inga vera, Trichilia catigua and Psidium guajava, common species for planting and the regeneration stratum, were found.

Regarding the successional classification, it is observed the almost totality of species distributed in pioneer species (11 species, $50 \%$ ) and early secondary (9 species; 40.9\%), where only 2 (9.1\%) species belong to late secondary class. At the level of individuals, the largest proportion found in the study was the pioneer class (107 individuals, $66 \%$ ), followed by early Secondary class (48 individuals; $29.6 \%$ ) and late secondary

Revista Árvore, Viçosa-MG, v.40, n.2, p.189-196, 2016 


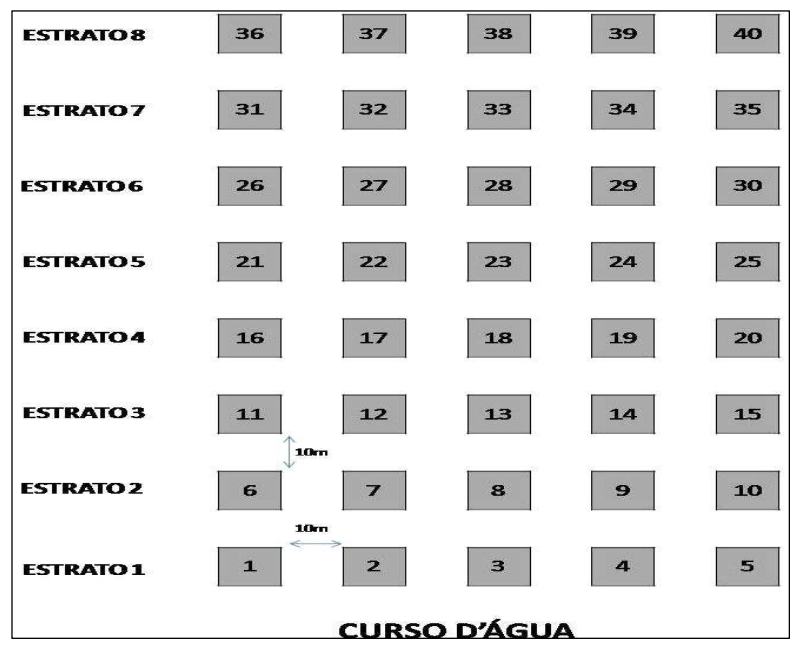

Figure 1 - Diagram of distribution of plots and strata for assessment of natural regeneration in the study area, company Holcim Brasil S/A, in the municipality of Barroso, MG.

Figura 1 - Esquema de distribuição das parcelas e estratos para avaliação da regeneração natural na área de estudo, empresa Holcim Brasil S/A, no município de Barroso, $M G$.

(7 individuals, 4.4\%). The predominant dispersion syndrome was zoochory (18 species; $81.8 \%$ ), followed by anemochory ( 3 species; $13.6 \%$ ) and autochory (1 species; $4.6 \%$ ). At the level of individuals, zoochory (137 individuals; $84.6 \%$ ) prevailed, followed by anemochory (24 individuals; $14.8 \%$ ) and autochory (1 individual; $0.6 \%$ ).

The watercourse and riparian vegetation present in the study area did not exercise significant influence ( $p>0.05)$ on the number of species and regenerating individuals among the different strata of the forest under restoration process.

The Shannon-Wiener diversity index (H') was 2.691 and the equability of Pielou was 0.870 . The species with the highest VI (importance value) was Psidium guajava, followed by Lithrea molleoides, Guettarda uruguensis, Schinus terebinthifolia, Piper aduncum and Baccharis dracunculifolia, totaling together $64.84 \%$ of the importance value and $61.73 \%$ of the individual totals. Consequently, families Myrtaceae, Anacardiaceae and Asteraceae, also stood out in the regenerative stratum, representing $67.77 \%$ of the IV for families and $66.05 \%$ of the sampled individuals. These same species and families were quite significant in cover value (CV), with few changes in order.

Revista Árvore, Viçosa-MG, v.40, n.2, p.189-196, 2016

\section{DISCUSSION}

The richness of sampled species and density of individuals were higher than those observed in other natural regeneration surveys conducted in environments where seedlings were planted at similar restoration time (SIQUEIRA, 2002; BASTOS, 2010). Yet, these parameters were quite lower than those found in seasonal mature semideciduous forests ( MARTINS et al., 2008; GARCIA et al., 2011). These observations prove that the restoration process is advancing, however, many species still need to be recruited from the seed bank or from external sources, so that the area under restoration resembles forests at a more advanced stage of succession.

The low floristic similarity among planted and regenerating individuals may be related to reproductive immaturity of those introduced in the planting, which are not producing propagules able to compose the regenerating stratum yet. The sampling method may also have affected because the plots of the natural regeneration may have not sampled species that present an essentially aggregated pattern. In addition, the dense layer of invasive alien grasses present in the study area, especially Melinis minutiflora, may be inhibiting the regeneration of shrub-tree species. This result proves that the seedlings coming from external sources are essential to the restoration process of this environment, highlighting the importance of different sources of propagules (local and immigrant) in the maintenance of floristic diversity in secondary forests (ALVEZ; METZGER, 2006).

The predominance of pioneer and early secondary species in the regenerating stratum is due to some features such as: abundant and continuous production of seed throughout the year, dispersion over great distances, formation of seed bank and high phenotypic plasticity (WHITMORE, 1990). The presence of these species is important for the restoration process because, due to rapid growth, they are able to shade the ground in a short time by naturally controlling the appearance of weeds and providing the staking of ombrophilous plants. In addition, because of their relatively short life cycle, they produce a considerable amount of biomass that, in turn, will turn into organic matter, which will be incorporated to the soil. The large amount of produced fruit will serve as food, mainly for birds, ensuring seed dispersal and the dynamics of the implanted forest (GOLÇALVES et al., 2005). 
Table 2 - Floristic composition of the species sampled in the regeneration stratum of a forest under restoration process, in the municipality of Barroso, state of Minas Gerais.

Table 2 - Composição florística das espécies amostradas no estrato de regeneração de uma floresta em processo de restauração, município de Barroso, $M G$.

\begin{tabular}{|c|c|c|c|c|c|}
\hline Family & Species & NI & $\mathrm{CS}$ & $\mathrm{SD}$ & VI $(\%)$ \\
\hline \multirow[t]{3}{*}{ Anacardiaceae } & Lithrea molleoides (Vell.) Engl. & 21 & $\mathrm{P}$ & Zoo & 12,32 \\
\hline & Schinus terebinthifolia Raddi & 10 & $\mathrm{P}$ & Zoo & 7,88 \\
\hline & Tapirira obtusa (Benth.) J.D. Mitch. & 14 & $\mathrm{Si}$ & Zoo & 6,76 \\
\hline \multirow[t]{3}{*}{ Asteraceae } & Baccharis dracunculifolia DC. & 13 & $\mathrm{P}$ & Ane & 7,45 \\
\hline & Gochnatia polymorpha (Less.) Cabrera & 3 & $\mathrm{P}$ & Ane & 2,87 \\
\hline & Vernonia polyanthes (Spreng.) Less. & 8 & $\mathrm{P}$ & Ane & 5,13 \\
\hline Erythroxylaceae & Erythroxylum deciduum A. St.-Hil. & 2 & St & Zoo & 1,30 \\
\hline \multirow[t]{2}{*}{ Euphorbiaceae } & Croton urucurana Baill. & 1 & $\mathrm{P}$ & Auto & 0,52 \\
\hline & Alchornea glandulosa Poepp. & 2 & $\mathrm{P}$ & Zoo & 0,88 \\
\hline Fabaceae & Inga vera Willd. & 4 & $\mathrm{Si}$ & Zoo & 2,23 \\
\hline Lauraceae & Ocotea odorifera (Vell.) Rohwer. & 5 & St & Zoo & 2,36 \\
\hline Meliaceae & Trichilia catigua A. Juss. & 3 & $\mathrm{Si}$ & Zoo & 1,33 \\
\hline Moraceae & Maclura tinctoria (L.) D. Don ex Steud. & 1 & $\mathrm{Si}$ & Zoo & 0,53 \\
\hline \multirow[t]{4}{*}{ Myrtaceae } & Psidium cattleyanum Sabine & 1 & $\mathrm{P}$ & Zoo & 0,53 \\
\hline & Psidium firmum O. Berg & 6 & $\mathrm{P}$ & Zoo & 3,91 \\
\hline & Psidium guajava L. & 28 & $\mathrm{P}$ & Zoo & 20,80 \\
\hline & Psidium rufum DC. & 3 & $\mathrm{Si}$ & Zoo & 1,65 \\
\hline Piperaceae & Piper aduncum L. & 14 & $\mathrm{P}$ & Zoo & 7,85 \\
\hline \multirow[t]{2}{*}{ Primulaceae } & Rapanea ferruginea (Ruiz e Pav.) Mez & 4 & $\mathrm{Si}$ & Zoo & 2,18 \\
\hline & Rapanea umbellata (Mart.) Mez & 3 & $\mathrm{Si}$ & Zoo & 2,03 \\
\hline Rubiaceae & Guettarda uruguensis Cham. e Schltdl. & 14 & $\mathrm{Si}$ & Zoo & 8,53 \\
\hline Sapindaceae & Allophylus edulis A. St.-Hil., Camb. e A. Juss. & 2 & $\mathrm{Si}$ & Zoo & 0,96 \\
\hline
\end{tabular}

$\mathrm{NI}=$ number of sampled individuals; $\mathrm{CS}=$ successional class: $\mathrm{P}=$ pioneer, $\mathrm{Si}=$ early secondary, $\mathrm{St}=1$ ate secondary; $\mathrm{SD}=\mathrm{dispersion}$ syndrome: $\mathrm{Zoo}=$ zoochory, Ane = anemochory, Auto = autochory; IV = importance value.

The results found for dispersion syndrome corroborate other natural regeneration surveys carried out in semideciduous seasonal forests (BASTOS, 2010;. FERREIRA et al., 2010; MIRANDA NETO, 2011) since tropical forests are characterized by presenting high proportions of plant species whose dispersion is performed by animals (STEFANELLO et al., 2010). The importance of zoochory dispersion syndrome for the restoration of the environment lies in the fact that this process allows the displacement of the propagule away from the mother plant, which reduces competition for local resources and potential rate of predation by insects or rodents (JANZEN, 1970; HOWE et al., 1985).

Although not significant ( $p>0.05$ ), the strata closest to the watercourse had the highest means for number of species and individuals (Figure 2).

The Shannon-Wiener diversity index ( $H^{\prime}$ ) demonstrates that the study area has low diversity of species. However, the result was higher than that found by Bastos (2010), in areas at seven $\left(\mathrm{H}^{\prime}=2.48\right)$ and nine years $(\mathrm{H}=1.60)$ of restoration. It is important to aim for a high diversity of species in restored

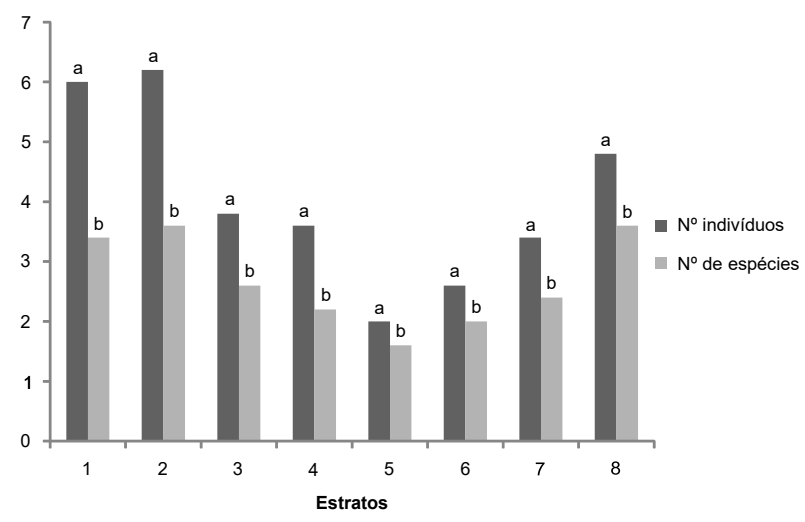

Figure 2- Mean number of individuals and number of regenerating species, per stratum in the forest restoration process, Barroso, MG. Values followed by the same letter within each group did not differ significantly by Tukey test $(0.05>\mathrm{p} \geq 0.01)$.

Figura 2-Médias de número de indivíduos e número de espécies regenerantes, por estrato, da floresta em processo de restauração, Barroso, MG. Valores seguidos de mesma letra dentro de cada grupo não diferem entre si significativamente pelo teste de Tukey $(0,05>p \geq 0,01)$.

Revista Árvore, Viçosa-MG, v.40, n.2, p.189-196, 2016

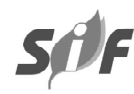


ecosystems, especially in the case of rain forests, which are inherently rich in species. However, many studies have shown that plantings with few species or even monospecific can accelerate the natural regeneration of vegetation, acting as "catalytic" of the forest restoration process. In other words, richness or initial species diversity do not matter if they do not form a set fitted to local conditions and are not able to survive and to quickly cover the soil, thereby, facilitating the continuity of the succession (DURIGAN et al., 2010).

The Pielou's equability value found in this study highlights that despite the low value of diversity found, the forest under restoration is heterogeneous, with low ecological dominance. This result is similar to that reported by Bastos (2010), in areas under restoration process for $7\left(\mathrm{~J}^{\prime}=0.860\right)$ and 9 years $\left(\mathrm{J}^{\prime}=0.890\right)$ and exceed the results obtained by Garcia et al. (2011) and Higuchi et al. (2006), with indexes ranging from 0.700 to 0.740 in semi-deciduous seasonal forest fragments.

The high importance value (IV) presented by the species Psidium guajava, Lithraea molleoides, Guettarda uruguensis, Schinus terebinthifolia, Piper aduncum and Baccharis dracunculifolia as well as the families Myrtaceae, Anacardiaceae and Asteraceae corroborate many natural regeneration surveys in semi-deciduos seasonal forests (SOARES, 2009; ARANTES et al., 2012; BILA, 2012), where such species and families stood out in the regenerating stratum, as well. This fact may be attributed to the following characteristics: pioneering, wide geographical distribution, adaptation to anthropized environments, with poor fertile soils and high light intensity, intrinsic of these families and their species.

\section{CONCLUSION}

Natural regeneration has proved to be a good indicator of the status of regeneration of an area as it showed the low diversity of regenerating shrub-tree species, mostly belonging to the early stages of regeneration. The results suggest the existence of barriers that disrupt the development of tree species, suggesting that corrective management actions are taken to accelerate the successional process.

\section{ACKNOWLEDMENTS}

We gratefully acknowledge the sponsorship by $\mathrm{CNPq}$ to the first and second authors and the financial support by Holcim Brasil S/A and José Alcino Organizations Ltda.

Revista Árvore, Viçosa-MG, v.40, n.2, p.189-196, 2016

\section{REFERENCES}

ALVES, L.F.; METZGER, J.P. A regeneração florestal em áreas de floresta secundária na Reserva Florestal do Morro Grande, Cotia, SP. Revista Biota Neotropica, v.6, n.2, p.1-26, 2006.

ARANTES, T.B.; FARIA, R.A.V.B.; SOUZA, L.M.; BOTELHO, S.A.; GUIMARÃES, J.C.C. Avaliação da regeneração natural como processo de recuperação do entorno de nascente perturbada. Enciclopédia Biosfera, v.8, n.14, p.10201041, 2012.

BAstos, S. C. Aplicação de indicadores de avaliação e monitoramento em um projeto de restauração florestal, Reserva Particular do Patrimônio Natural-RPPN, Fazenda Bulcão, Aimorés, MG. 2010. 118f. Dissertação (Mestrado em Ciência Florestal) - Universidade Federal de Viçosa, Viçosa, MG, 2010.

BILA, N. Avaliação da recuperação de área degradada na represa do Iraí, Paraná, por meio de aspectos florísticos e fitossociológicos. 2012. $110 \mathrm{f}$. Dissertação (Mestrado) - Universidade Federal do Paraná, Curitiba, 2012.

DURIGA, G.; ENGEL, V.L.; TOREZAN, J.M.; MELO, C.G.; MARQUES, M.C.M.; MARTINS, S.V.; REIS, A.; SCARANO, F.R. Normas jurídicas para a restauração ecológica: uma barreira a mais a dificultar o êxito das iniciativas? Revista Árvore, v.34, n.3, p.471-485, 2010.

EMPRESA BRASILEIRA DE PESQUISA AGROPECUÁRIA - EMBRAPA. Levantamento de Reconhecimento de média intensidade dos solos da Zona Campos das Vertentes-MG. Rio de Janeiro: Embrapa Solos, 2006. 326p.

ENGEL, V.L.; PARROTA, J.A. Definindo a restauração ecológica: tendências e perspectivas mundiais. In: KAGEYAMA, P.Y.; OLIVEIRA, R.E.; MORAES, L.F.D.; ENGEL, V.L.; GANDARA, F.B. (Ed.). Restauração ecológica de ecossistemas naturais. Botucatu: FEPAF, 2003. p.3-26. 
FERREIRA, C.W.; BOTELHO, S.A.; DAVIDE, A.C.; FARIA, J.M.P.; FERREIRA, D.F. Regeneração Natural como indicador de recuperação de área degradada a jusante da usina hidrelétrica de Camargos, MG. Revista Árvore, v.34, n.4, p.651-660, 2010.

GANDOLFI, S.; LEITÃO FILHO, H. F.; BEZERRA, C. L. E. Levantamento florístico e caráter sucessional das espécies arbustivo arbóreas de uma floresta mesófila semidecídua no município de Guarulhos, SP. Revista Brasileira de Biologia, v. 55, n. 4, p. 753-767, 1995.

GARCIA, C.C.; REIS, M.G.F.; REIS, G.G.; PEZZOPANE, J.E.M.; LOPES, H.N.S.; RAMOS, D.C. Regeneração natural de espécies arbóreas em fragmento de floresta estacional semidecidual montana, no domínio da mata atlântica, em Viçosa, MG. Ciência Florestal, v. 21 , n.4, p.677-688, 2011.

GONÇALVES, R.M.G.; GIANNOTTI, E.; GIANNOTTI, J.D.G.; SILVA, A.A. Aplicação de modelo de revegetação em áreas degradadas, visando à restauração ecológica da microbacia do córrego da fazenda Itaqui, no Município de Santa Gertrudes, SP. Revista Instituto Florestal, v.17, n.1, p.73-95, 2005.

HIGUCHI, P.; REIS, M.G.F.; REIS, G.G.; PINHEIRO, A.L.; SILVA, C.T.; OLIVEIRA, C.H.R. Composição florística da regeneração natural de espécies arbóreas ao longo de oito anos em um fragmento de floresta estacional semidecidual em Viçosa, MG. Revista Árvore, v.30, n.6, p.893-204, 2006.

HOWE, H.F.; SCHUPP, E.W.; WESTLEY, L.C. Early consequences of seed dispersal for a Neotropical tree (Virola surinamensis). Ecology, v.66, n.3, p.781-791, 1985.

JANZEN, D.H. Herbivores and the number of tree species in tropical forests. American Naturalist, v. 104, n.940, p.501-529, 1970.

MAGURRAN, A.E. Ecological diversity and its measurement. Londres: Croom Hell, 1988. 179 p.

MARANGON, L.C.; FELICIANO, A.L.P.; BRANDÃO, C.F.L.S.; ALVES JUNIOR, F.T. Relações florísticas, estrutura diamétrica e hipsométrica de um fragmento de floresta estacional semidecidual em Viçosa (MG). Floresta, v.38, n.4, p.699-709, 2008.

MARTINS, S.V.; RODRIGUES, R.R. Assessing the role of the canopy gap characteristics in the regeneration of shrub and tree species in a Semideciduos Mesophytic Forest in SouthEastern Brazil. In: BURK, A.R. (Ed.). New Research on Forest Ecosystems. New York: Nova Science Publishers, 2005. p.93-112.

MARTINS, S.V.; GLERIANI, J.M.; AMARAL, C.H.; MACIEL, T. Caracterização do dossel e do estrato de regeneração natural no sub-bosque e em clareiras de uma Floresta Estacional Semidecidual no Município de Viçosa, MG. Revista Árvore, v.32, n.4, p.759-767, 2008.

MARTINS, S.V. Recuperação de áreas degradadas: ações em Áreas de Preservação Permanente, voçorocas, taludes rodoviários e de mineração. Viçosa, MG: Aprenda Fácil, 2009. 270p.

MELO, A.C.G.; DURIGAN, G. Evolução estrutural de reflorestamentos de restauração de matas ciliares no Médio Vale do Paranapanema.

Scientia Florestalis, n.73, p.101-111, 2007.

MIRANDA NETO, A. Avaliação do componente arbóreo, da regeneração natural e do banco de sementes de uma floresta restaurada com 40 anos, Viçosa, MG. 2011. 146f. Dissertação (Mestrado em Ciência Florestal) - Universidade Federal de Viçosa, Viçosa, MG, 2011.

MUELLER-DOMBOIS, D.; ELLENBERG, H. Aims and methods of vegetation ecology. New York: John Wiley \& Sons, 1974. 547p.

MENINI NETO, L.; ASSIS, L.C.S.; FORZZA, R.C. A família Orchidaceae em um fragmento de floresta estacional semidecidual, no município de Barroso, Minas Gerais, Brasil. Lundiana, v.4, n. 1, p.9-24, 2004.

MARTINS NETO, R.G.M.; RAMALHO, J.S. A evolução do impacto ambiental acarretado pela extração de calcário, tendo como exemplo a mineração Patercal-Partezani, no estado de São Paulo. CES Revista, v.24, p.31-42, 2010.

Revista Árvore, Viçosa-MG, v.40, n.2, p.189-196, 2016 
OLIVEIRA-FILHO, A.T.; MACHADO, J.M.N Composição florística de uma floresta semidecídua montana na Serra de São José, Tiradentes, Minas Gerais. Acta Botanica Brasilica, v. 7, n. 1, p.71-88, 1993.

PIELOU, E.C. Ecological diversity. New York: John Willey, 1975. 165p.

van der PIJL, L. Principles of dispersal in higher plants. $3^{\circ}$ ed. Berlin/New York: Springer-Verlag, 1982. 214p.

RODRIGUES, R.R.; LIMA, R.A.F.; GANDOLFI, S.; NAVE, A. On the restoration of high diversity forests: 30 years of experience in the Brazilian Atlantic Forest. Biological Conservation, v.142, n.6, p.1242-1251, 2009.

RODRIGUES, R.R.; GANDOLFI, S.; NAVE, A.G.; ARONSON, J.; BARRETO, T.E.; VIDAL, C.Y.; BRANCALION, P.H.S. Large-scale ecological restoration of high-diversity tropical forests in SE Brazil. Forest Ecology and Management, v.261, n.10, p.1605-1613, 2011.

SHEPHERD, G.J. Fitopac 2.1 - Campinas: Universidade Estadual de Campinas, 2010.
SIQUEIRA, L.P. Monitoramento de áreas restauradas no interior do Estado de São Paulo, Brasil. 2002. 116f. Dissertação (Mestrado em Recursos Florestais) - Escola Superior de Agricultura Luiz de Queiroz, Piracicaba, 2002.

SOARES, P. Levantamento fitossociológico de regeneração natural em reflorestamento misto no noroeste de Mato Grosso. 2009. 49f. Dissertação (Mestrado em Ciencias Florestais e Ambientais) - Universidade Federal do Mato Grosso, Cuiabá, 2009.

STATSOFT, INC. Statistica - Data analysis software system. Version 7.0.61.0. Tulsa: 2004.

STEFANELLO, D.; IVANAUSKAS, N.M.; MARTINS, S.V.; KUNZ, S.H. Síndromes de dispersão de diásporos das espécies de trechos de vegetação ciliar do rio das Pacas, Querência - MT. Acta Amazonica, v.40, n.1, p.141-150, 2010.

WHITMORE, T.C. Tropical Rain Forest dynamics and its implications for management. In: GOMESPOMPA, A.; WHITMORE, T.C.; HADLEY, $M$. Rain forest regeneration and management. Paris: UNESCO and The Part Eenon Publishing Group, 1990. p.67-89. 